\title{
Perbandingan Pengaruh Laba dan Value Added pada Return Saham
}

\author{
Gentha Putri Wardana ${ }^{1}$ \\ Dewa Gede Wirama
}

\author{
${ }^{1,2}$ Fakultas Ekonomi dan Bisnis Universitas Udayana (Unud), Bali, Indonesia \\ e-mail: genthawardana@gmail.com
}

\begin{abstract}
ABSTRAK
Informasi value added dianggap dapat mengukur kinerja perusahaan dan berasosiasi lebih baik dengan return saham dibandingkan dengan informasi laba yang sering digunakan. Penelitian ini bertujuan untuk membandingkan relative information content pada laba dan value added dalam menjelaskan return saham. Penelitian ini dilakukan pada semua perusahaan yang terdaftar di Bursa Efek Indonesia pada tahun 2013-2017. Jumlah sampel sebanyak 308 diperoleh dengan metode random sampling. Teknik analisis data yang digunakan adalah regresi linear sederhana. Berdasarkan nilai adjusted $R^{2}$ dari hasil regresi ditemukan bahwa EVA dan FVA sebagai proksi dari value added mengungguli laba dalam pengaruhnya pada return saham. EVA juga ditemukan lebih berasosiasi dengan return saham jika dibandingkan dengan FVA. Implikasi teoritis penelitian adalah sebagai tambahan referensi mengenai pengukuran kinerja perusahaan dan return saham. Implikasi praktis penelitian adalah sebagai bahan pertimbangan bagi investor untuk mengambil keputusan investasi. Bagi perusahaan penelitian ini dapat digunakan sebagai referensi pengambilan keputusan keuangan sesuai preferensi pemegang saham.
\end{abstract}

Kata kunci: Laba, economic value added, financial value added, return saham, relative information content

\begin{abstract}
The information of value added is considered to be a better company performance measure and has better association on stock returns compared to earning information that is often used. This study aims to compare the relative information content of earnings and value added in explaining stock returns. This research conducted on all companies listed on the Indonesia Stock Exchange in 2013-2017. 308 samples were taken using random sampling method. The data analysis technique was simple linear regression. It was found that EVA and FVA as proxies of value added outperformed earnings. EVA is also found to be more associated with stock returns compared to FVA. The theoretical implication is in addition to references to further research regarding company performance measurement and stock returns. The practical implications is a matter of consideration for investors to make investment decisions and reference for corporate in financial decision making according to preferences of shareholders.
\end{abstract}

Keywords: Earning, economic value added, financial value added, stock return, relative information content

\section{PENDAHULUAN}

Investasi pada saham menghasilkan return berupa pendapatan dividen dan pendapatan yang berasal dari selisih antara harga jual dan harga beli saham (capital gain). Return saham secara umum dipengaruhi oleh berbagai faktor, salah 
satunya fundamental perusahaan. Bagi investor, faktor tersebut memberikan gambaran yang jelas mengenai prospek saham yang dipilih mengacu pada kondisi perusahaan penerbit saham (Suandewi dan Sudana, 2016).

Nilai fundamental atau nilai intrinsik saham mencerminkan nilai sebenarnya dari perusahaan. Nilai intrinsik dapat dianalisis menggunakan data fundamental yang berasal dari data keuangan perusahaan (Hartono, 2015: 188). Dalam data keuangan perusahaan terkandung informasi akuntansi yang memberi reaksi pada harga saham (Wang et al., 2013). Salah satu informasi akuntansi yang menjadi sorotan utama dalam keputusan investasi pada saham adalah laba. Laba merupakan informasi perusahaan yang paling diminati dalam pasar uang dan modal (Wild et al., 2014: 408). Investor menggunakan laba untuk mengetahui prospek perusahaan di masa yang akan datang karena laba dapat mencerminkan kinerja manajemen perusahaan (Yatmi et al., 2016). Laba yang baik umumnya menghasilkan keuntungan bagi investor dan sebaliknya.

Penelitian pada Bucharest Stock Exchange di Romania menemukan bahwa informasi akuntansi seperti laba relevan dengan return saham yang dihasilkan (Jianu et al., 2014). Pengujian pada Mexican Bolsa selaku bursa pasar modal di Meksiko juga menemukan bahwa laba berpengaruh secara positif dan signifikan terhadap return saham (Dorantes, 2013). Hasil serupa ditunjukan pada penelitian di bursa Malaysia di mana laba akuntansi mempengaruhi return saham (Nakhaei dan Hamid, 2016). Di Indonesia, penelitian mengenai pengaruh laba pada return saham yang dilakukan oleh Tumbel et al. (2017) menemukan bahwa laba akuntansi berdampak pada return saham. 
Riset pasar modal yang dilakukan selama bertahun-tahun tidak dapat menunjukkan adanya determinan tunggal yang dapat diandalkan untuk memprediksi pasar secara menguntungkan. Informasi laba yang banyak digunakan juga tidak dapat memberikan informasi kinerja perusahaan dengan sempurna. Laba akuntansi dikritisi karena tidak mempertimbangkan total biaya modal dan dinyatakan berdasarkan informasi akuntansi yang bisa terdistorsi oleh prinsip akuntansi yang berlaku umum (Nakhaei dan Hamid, 2016). Untuk mengatasi permasalahan yang timbul dalam pengukuran kinerja keuangan berdasarkan data akuntansi, maka timbullah pemikiran pengukuran kinerja keuangan menggunakan value based (Pahlevi et al., 2013).

Value based digunakan sebagai filosofi dalam manajemen dan dikenal sebagai value-based management (VBM). VBM merupakan filosofi yang menggunakan alat dan proses analitis untuk memfokuskan organisasi untuk mencapai tujuan tunggal, yaitu menciptakan nilai bagi pemegang saham. Komponen value-based management meliputi strategi perusahaan, pelaporan kinerja dan kompesasi insentif, cara dan bantuan yang digunakan untuk menciptakan organ dan karyawan perusahaan agar bertindak seperti pemegang saham, serta pembuatan keputusan yang dapat memaksimalkan nilai perusahaan. Keputusan-keputusan tersebut pada akhirnya diharapkan mengarah pada perbaikan kinerja dan harga saham dalam jangka panjang. Dalam penelitian ini pengukuran kinerja perusahaan dengan value based dilakukan menggunakan proksi economic value added dan financial value added. 
Economic value added (EVA) awalnya digagas oleh consulting firm Stern Stewart \& Co. yang memperkenalkan konsep tersebut untuk membantu kliennya dalam mengukur dan menciptakan keuntungan bagi pemegang saham. Konsep ini awalnya tidak banyak diperhatikan hingga akhirnya mencuri perhatian perusahaan besar seperti AT\&T, Coca Cola, Du-Pont, General Electric, Quaker Oats, Pepsi dan berbagai perusahaan besar lainnya. Para eksekutif dari perusahaan-perusahaan tersebut menyatakan bahwa EVA dapat meningkatkan nilai saham perusahaan menuju level yang lebih tinggi (Bhasin, 2017). Stern Stewart \& Co. menyatakan bahwa laba, laba per saham, dan pertumbuhan laba merupakan pengukuran kinerja perusahaan yang menyesatkan. Pengukuran kinerja perusahaan terbaik dapat dilakukan menggunakan EVA. EVA merupakan pengukuran yang lebih mencerminkan kinerja keuangan dan keuntungan ekonomi perusahaan yang sesungguhnya dibandingkan dengan pengukuran lain. EVA juga merupakan pengukuran kinerja yang paling berkaitan secara langsung dengan kekayaan pemegang saham dari waktu ke waktu (Shah et al, 2015). Penggunaan EVA mendorong perusahaan untuk memusatkan modal dan meningkatkan jumlah return secara lebih cepat dibandingkan dengan biaya modal dengan cara meningkatkan penggunaan leverage (Nakhaei dan Hamid, 2016).

Seiring dengan perkembangan, EVA banyak diuji oleh peneliti dari berbagai negara. EVA secara positif dan signifikan berkorelasi dengan kinerja saham pada perusahaan-perusahaan go public di Iran (Baybordi et al., 2013). Pada industri otomotif di India, EVA disebut memiliki kualifikasi yang signifikan dalam mengevaluasi performa perusahaan. Perusahaan dengan nilai EVA 
memuaskan memberikan return saham secara konsisten (Sandhar et al., 2014). Ditemukan juga bahwa EVA lebih relevan dan lebih berasosiasi secara positif dengan return saham dibandingkan dengan pengukuran tradisional seperti laba (Gupta dan Sikarwar, 2016).

Beberapa tahun setelah EVA diperkenalkan penelitian mengenai pengukuran dengan value added semakin berkembang. Dalam penelitiannya, Rodríguez, et al. (2002) memperkenalkan metode pengukuran baru yang dikenal sebagai financial value added (FVA). FVA disebut dapat mencocokkan hasilnya sesuai ketentuan diskonto pada net present value. Jika EVA menggunakan biaya modal sebagai dasar penentuan nilai tambah perusahaan, FVA menggunakan aset tetap. FVA mengukur kontribusi dari aset tetap dalam menghasilkan keuntungan bersih bagi perusahaan. Kinerja FVA dinilai lebih baik dibanding EVA, terutama dalam hal sinkronisasi hasil pengukurannya dengan hasil NPV.

Tinggi rendahnya return saham suatu perusahaan mencerminkan nilai perusahaan di mata masyarakat. Apabila return saham suatu perusahaan tinggi, maka nilai perusahaan di mata masyarakat juga baik dan begitu juga sebaliknya. Return saham menjadi hal yang penting baik bagi investor maupun perusahaan sehingga mendorong perkembangan berbagai metode sebagai upaya untuk menilai fundamental perusahaan dan menghasilkan prediksi return saham secara tepat.

Berdasarkan penelitian-penelitian sebelumnya laba, economic value added, dan financial value added diakui dapat memprediksi dan memberikan gambaran mengenai return saham dengan sangat baik. Laba dinyatakan sebagai variabel yang mendapat perhatian besar dari investor untuk membuat keputusan investasi. 
Meski sering digunakan sebagai bahan pertimbangan, di sisi lain laba dikritisi karena tidak dapat menjelaskan kinerja perusahaan sesuai dengan keadaan sebenarnya. Untuk menutupi kekurangan dari pengukuran menggunakan laba, pengukuran dengan value added diklaim sebagai solusi yang lebih baik. Pengukuran menggunakan economic value added bahkan disebut sebagai prediktor nilai saham yang lebih baik dari pengukuran lainnya.

Setelah economic value added, ada berbagai metode pengukuran nilai tambah yang lahir dari berbagai penelitian. Salah satu metode pengukuran tersebut adalah financial value added. Dalam pengukuran menggunakan value added, FVA diklaim lebih baik dari EVA utamanya dalam sinkronisasi dengan net present value dari perusahaan.

Merujuk dari kekurangan dan kelebihan serta penelitian sebelumnya, laba, EVA dan FVA perlu diuji dan dibandingkan untuk mengetahui pengaruhnya pada return saham sesuai dengan kondisi pasar modal di Indonesia. Berdasarkan hal ini maka peneliti tertarik untuk mengambil judul "Perbandingan Pengaruh Laba dan Value Added pada Return Saham.”

Perbandingan laba, economic value added, dan financial value added dalam penelitian ini melibatkan semua perusahaan yang tercatat di Bursa Efek Indonesia pada tahun 2013-2017. Pemilihan populasi seluruh perusahaan dalam jangka waktu lima tahun dapat menggambarkan kondisi pasar modal Indonesia dengan data terbaru. Perusahaan-perusahaan tersebut merupakan perusahaan go public yang berkewajiban melakukan publikasi atas laporan tahunan serta laporan keuangan. Laporan yang dipublikasi dapat dipergunakan sebagai bahan 
pertimbangan untuk meninjau laba dan value added yang dihasilkan perusahaan serta hubungannya terhadap return saham.

Stewart. Co merilis EVA sebagai metode pengukuran kinerja perusahaan dan banyak penelitian yang dilakukan untuk menguji bagaimana EVA dapat berhubungan dengan return saham. Pada tahun 1991 Stewart menyatakan dalam bukunya "The Quest for Value" bahwa EVA lebih baik dibandingkan laba, laba per saham dan pertumbuhan laba. Stewart juga memberi pernyataan di Harvard Business Review bahwa sudah saatnya melupakan pengukuran berbasis data akuntansi seperti EPS, ROE, dan ROI. Hasil penelitian yang dilakukan oleh Gupta dan Sikarwar (2016) mendukung bahwa EVA lebih berasosiasi dengan return saham dibandingkan pengukuran dengan akuntansi tradisional seperti laba. Penelitian yang dilakukan oleh Awan et al. (2014) juga menghasilkan kesimpulan bahwa EVA lebih dominan berpengaruh pada return saham dibandingkan dengan laba.

Hasil berbeda ditemukan dalam penelitian yang dilakukan oleh Yusbardini (2017) yang membandingkan pengaruh EVA dan laba pada return saham. Hasil penelitiannya menyatakan bahwa EVA dan laba berpengaruh signifikan pada return saham dengan laba memberi pengaruh lebih besar. Penelitian sejenis pada bursa di Pakistan juga menghasilkan kesimpulan bahwa laba lebih berpengaruh pada return saham jika dibandingkan dengan EVA (Khan et al., 2016).

Berdasarkan kajian tersebut, maka hipotesis dalam penelitian ini ditentukan sebagai berikut:

$\mathrm{H}_{1}$ : Economic value added lebih berpengaruh pada return saham dibandingkan dengan laba. 
Laba dianggap sebagai informasi paling menarik di pasar modal dan pasar uang karena dapat menjadi pengukuran perubahan kekayaan pemegang saham dan dapat digunakan untuk menganalisis usaha di masa depan. Perusahaan dengan laba yang baik menggambarkan kondisi fundamental perusahaan yang baik sehingga diminati oleh investor, begitu juga sebaliknya. Hal ini memicu perubahan harga saham sesuai dengan permintaan dan penawaran yang dilakukan oleh investor di pasar modal. Pembahasan tersebut selaras dengan hasil penelitian yang dilakukan oleh Nazemi dan Abdoli (2015) dan Tumbel et al. (2017) yang menemukan bahwa return saham berkaitan dengan laba akuntansi.

Di sisi lain laba akuntansi diklaim memiliki kekurangan dalam menjelaskan performa perusahaan sehingga berpengaruh pada kemampuannya dalam memprediksi return saham (Nakhaei et al., 2016). Pengukuran menggunakan value-based measurement disebut berasosiasi lebih baik dengan return saham. Sebagai salah satu metode value-based measurement, economic value added sebelumnya diklaim lebih baik dalam menjelaskan performa perusahaan dibandingkan dengan laba sehingga dapat digunakan sebagai prediktor return saham yang lebih baik. Lebih lanjut, financial value added dinyatakan dapat mengungguli kemampuan EVA dalam mengukur performa perusahaan. Variabel financial value added sebelumnya pernah diteliti pada perusahaan yang masuk dalam indeks papan utama di Bursa Efek Indonesia dan dinyatakan berpengaruh siginifkan pada return saham (Handayani, 2016).

Berdasarkan kajian tersebut, maka hipotesis dalam penelitian ini ditentukan sebagai berikut: 
$\mathrm{H}_{2}$ : Financial value added lebih berpengaruh pada return saham dibandingkan dengan laba.

Tambahan nilai perusahaan yang digambarkan dalam selisih keuntungan dengan biaya modal menggambarkan kinerja yang diharapkan oleh prinsipal. Sinyal baik tersebut dapat digambarkan dengan tingginya permintaan akan saham dan menyebabkan kenaikan harga saham sehingga pada akhirnya menghasilkan return yang lebih tinggi. Penelitian yang dilakukan oleh Sauro dan Tafirei (2016) dan Hidajat (2018) menghasilkan kesimpulan bahwa EVA berpengaruh signifikan terhadap return saham. Disebutkan pula bahwa perusahaan yang menggunakan EVA pada pengukurannya memiliki kinerja harga saham yang lebih baik dibanding dengan yang tidak.

Ketika perusahaan telah berhasil menciptakan keuntungan di atas jumlah equivalent depresiasi, perusahaan dianggap dapat menciptakan nilai tambah. Perhitungan nilai tambah tersebut dijelaskan dengan perhitungan financial value added. FVA memiliki kemampuan mengukur nilai tambah dan menggambarkan keadaan perusahaan, bahkan lebih baik dari EVA (Rodríguez, 2002). Kusumaningtyas (2016) dalam penelitiannya menemukan bahwa FVA berasosiasi dengan harga saham.

Berdasarkan kajian penelitian sebelumnya, maka hipotesis dalam penelitian ini ditentukan sebagai berikut :

$\mathrm{H}_{3}$ : Financial value added lebih berpengaruh pada return saham dibandingkan dengan economic value added. 


\section{METODE PENELITIAN}

Penelitian dilakukan pada perusahaan yang terdaftar di Bursa Efek Indonesia pada periode 2013-2017. Data diperoleh situs www.idx.co.id, www.web.idx.id, dan www.finance.yahoo.com.

Return saham dihitung dengan rumus berikut:

$$
\text { Return Saham }=\frac{P_{t}-P_{t-1}}{P_{t-1}}+\frac{D_{t}}{P_{t-1}}
$$

Keterangan:

$\mathrm{P}_{\mathrm{t}} \quad$ = harga saham tahun sekarang

$\mathrm{P}_{\mathrm{t}-1}=$ harga saham tahun sebelumnya

$\mathrm{D}_{\mathrm{t}}=$ dividen tahun sekarang

Laba diukur menggunakan perubahan laba bersih $(\Delta \mathrm{L} / \mathrm{R})$ atau dihitung dengan menggunakan rumus sebagai berikut:

$$
\Delta \text { Laba bersih }=\frac{\text { Laba bersih }_{t}-\text { Laba bersih }_{t-1}}{{\text { Laba } \text { bersih }_{t-1}}}
$$

Economic value added adalah tolok ukur kinerja keuangan dengan mengukur perbedaan antara laba atas modal perusahaan dan biaya modal (Firdausi et al., 2017). Dalam penelitian ini EVA dihitung dengan rumus sebagai berikut:

$$
\mathrm{EVA}=\mathrm{NOPAT}-(\mathrm{WACC} \times \mathrm{IC})
$$

Tabel 1.

Langkah Perhitungan EVA

\begin{tabular}{ll}
\hline \multicolumn{1}{c}{ Komponen EVA } & \multicolumn{1}{c}{ Rumus } \\
\hline NOPAT & EBIT x (1-Tarif Pajak) \\
WACC & $\mathrm{W}_{\mathrm{d}} \times \mathrm{k}_{\mathrm{d}}\left(1-\right.$ Tarif Pajak) $+\mathrm{W}_{\mathrm{s}} \times \mathrm{k}_{\mathrm{s}}$ \\
IC & (Total Hutang + Total Ekuitas ) - Total Hutang Jangka Pendek \\
\hline Sumber: Data diolah, 2018 &
\end{tabular}

Keterangan:

EVA $=$ Economic Value Added

NOPAT $=$ Net Operating Profit after Tax (Laba Operasi Bersih Setelah Pajak)

EBIT = Earning Before Interest and Taxes (Laba Sebelum Bunga dan Pajak). 


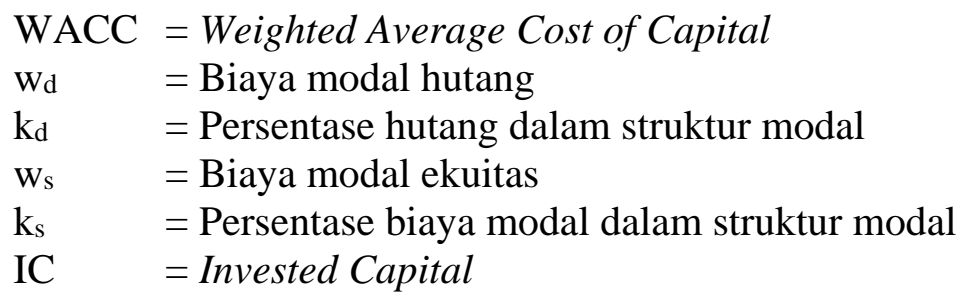

Dari perhitungan akan diperoleh kesimpulan dengan interprestasi hasil sebagai berikut: Jika EVA > 0 hal ini menunjukkan terjadi nilai tambah ekonomis bagi perusahaan. Jika EVA $<0$ hal ini menunjukkan tidak terjadi nilai tambah ekonomis bagi perusahaan. Jika EVA $=0$ hal ini menunjukkan posisi impas karena laba telah digunakan untuk membayar kewajiban kepada penyandang dana baik kreditur maupun pemegang saham.

Financial value added adalah metode pengukuran kinerja dan nilai tambah suatu perusahaan dengan mempertimbangkan kontribusi aktiva tetap dalam menghasilkan laba bersih perusahaan (Wijaya, 2017). Perhitungan FVA diperoleh dengan menggunakan rumus berikut:

$$
\mathrm{FVA}=\mathrm{NOPAT}-(\mathrm{ED}-\mathrm{D})
$$

Tabel 2.

Langkah Perhitungan FVA

\begin{tabular}{ll}
\hline Komponen FVA & Rumus \\
\hline NOPAT & Laba bersih $(1-$ tarif pajak) \\
ED & k x TR \\
TR & Hutang Jangka Panjang + Total ekuitas \\
\hline Sumber: &
\end{tabular}

Sumber: Data diolah, 2018

Keterangan:

FVA = Financial Value Added

NOPAT $=$ Net Operating Profit after Taxes (Laba Operasi Bersih Setelah Pajak)

$\mathrm{ED}=$ Equivalent Depreciation

TR $=$ Total Resources

$\mathrm{D} \quad=$ Depresiasi

$\mathrm{k} \quad=$ Weighted Average Cost of Capital

Interpretasi dari hasil pengukuran FVA dapat dijelaskan sebagai berikut: 
Nilai FVA $>0$ atau FVA bernilai positif menunjukkan terjadi nilai tambah finansial bagi perusahaan. Nilai FVA = 0 menunjukkan posisi impas. Nilai FVA < 0 atau FVA bernilai negatif menunjukkan tidak terjadi nilai tambah finansial bagi perusahaan.

Regresi linier sederhana didasarkan pada hubungan fungsional ataupun kausal satu variabel independen dengan satu variabel dependen. Dalam penelitian ini model yang digunakan dalam regresi linear sederhana ditunjukan dalam persamaan sebagai berikut:

$\begin{array}{ll}\mathrm{Y} & =\mathrm{a}+\mathrm{b}_{1} \mathrm{X}_{1}+\mathrm{ei} \\ \mathrm{Y} & =\mathrm{a}+\mathrm{b}_{2} \mathrm{X}_{2}+\mathrm{ei} \\ \mathrm{Y} & =\mathrm{a}+\mathrm{b}_{3} \mathrm{X}_{3}+\mathrm{ei}\end{array}$

Keterangan:

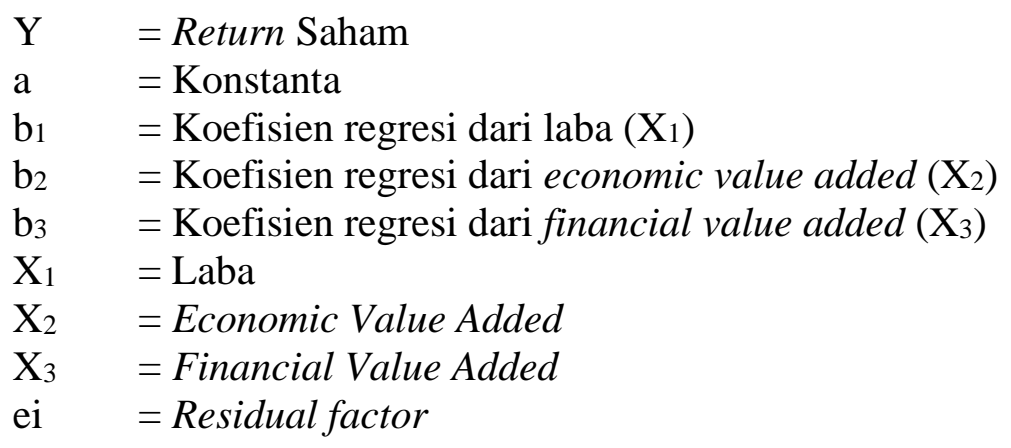

\section{HASIL DAN PEMBAHASAN}

Dalam penelitian ini statistik deskriptif digunakan untuk melihat nilai rata-rata, nilai minimum, nilai maksimum, dan standar deviasi. Hasil uji statisik desktriptif dalam penelitian ini dapat dilihat pada Tabel 3. 
Tabel 3.

Hasil Statistik Deskriptif

\begin{tabular}{lcrrrr}
\hline & $\mathrm{N}$ & \multicolumn{1}{c}{ Minimum } & \multicolumn{1}{c}{ Maximum } & \multicolumn{1}{c}{ Mean } & \multicolumn{1}{c}{ Std. Deviation } \\
\hline Return & 308 &,- 7778 &, 7274 &,- 017938 &, 3096871 \\
Saham & & & & & \\
Laba & 308 & $-102,2442$ & 31,3107 &,- 604577 & 8,1328757 \\
EVA & 308 & - & 13994250530718 & 304292266900 & 1876614869519 \\
& & 5051869223669 & & & \\
FVA & 308 & - & 32528250530718 & 694239320783 & 2732004355557 \\
& & 3841166413312 & & & \\
\hline
\end{tabular}

Sumber: Data diolah, 2018

Variabel return saham memiliki nilai minimum sebesar minus 0,7778

yang berarti bahwa nilai terendah return saham pada perusahaan yang masuk dalam sampel sebesar minus 0,7778. Nilai maksimum sebesar 0,7274 yang berarti nilai tertinggi return saham pada perusahaan yang masuk dalam sampel sebesar 0,7274 . Nilai rata-rata pada variabel return saham sebesar $-0,017938$. Deviasi standar variabel return saham sebesar 0,309687. Hal ini menunjukkan bahwa standar penyimpangan data terhadap nilai rata-ratanya sebesar 0,309687.

Variabel laba memiliki nilai minimum sebesar minus 102,2442 yang berarti bahwa nilai terendah perubahan laba perusahaan yang masuk dalam sampel sebesar minus 102,2442. Nilai maksimum sebesar 31,3107 yang berarti nilai tertinggi perubahan laba pada perusahaan yang masuk dalam sampel sebesar 31,3107. Nilai rata-rata pada variabel laba sebesar minus 0,604577. Deviasi standar variabel laba sebesar 8,1328757 . Hal ini menunjukkan bahwa standar penyimpangan data terhadap nilai rata-ratanya sebesar 8,1328757 .

Variabel economic value added memiliki nilai minimum minus 5.051.869.223.669 yang berarti bahwa nilai terendah EVA perusahaan yang masuk dalam sampel sebesar minus 5.051.869.223.669. Nilai maksimum sebesar 13.994.250.530.718 yang berarti nilai tertinggi EVA pada perusahaan yang masuk 
dalam sampel sebesar 13.994.250.530.718. Nilai rata-rata pada variabel EVA sebesar 304.292.266.900. Deviasi standar variabel EVA sebesar 1.876.614.869.519. Hal ini menunjukkan bahwa standar penyimpangan data terhadap nilai rata-ratanya sebesar 1.876.614.869.

Variabel financial value added memiliki nilai minimum minus 3.841.166.413.312 yang berarti bahwa nilai terendah FVA perusahaan yang masuk dalam sampel sebesar minus 3.841.166.413.312. Nilai maksimum sebesar 32.528.250.530.718 yang berarti nilai tertinggi FVA pada perusahaan yang masuk dalam sampel sebesar 32.528.250.530.718. Nilai rata-rata pada variabel FVA sebesar 694.239.320.783. Deviasi standar variabel FVA sebesar 2.732.004.355.557. Hal ini menunjukkan bahwa standar penyimpangan data terhadap nilai rata-ratanya sebesar 2.732.004.355.557.

Penelitian ini menggunakan regresi linear sederhana untuk mengetahui pengaruh variabel independen terhadap variabel dependen. Regresi dilakukan pada masing-masing variabel independen yaitu laba, economic value added, dan financial value added pada variabel dependen, yaitu return saham.

Hasil regresi laba pada return saham disajikan dalam Tabel 4 berikut.

Tabel 4.

Hasil Analisis Regresi Linear Sederhana Laba pada Return Saham

\begin{tabular}{|c|c|c|c|c|c|c|}
\hline & \multirow[t]{2}{*}{ Model } & \multicolumn{2}{|c|}{$\begin{array}{l}\text { Unstandardized } \\
\text { Coefficients }\end{array}$} & \multirow{2}{*}{$\begin{array}{c}\text { Standardized } \\
\text { Coefficients } \\
\text { Beta }\end{array}$} & \multirow[t]{2}{*}{$\mathrm{t}$} & \multirow[t]{2}{*}{ Sig. } \\
\hline & & B & Std. Error & & & \\
\hline \multirow{2}{*}{1} & (Constant) & -.020 & .018 & & -1.127 & 0,261 \\
\hline & Laba & -.003 & 0.002 & -.085 & -1.492 & 0,137 \\
\hline
\end{tabular}

Sumber: Data diolah, 2018

Nilai konstanta -0,020 menunjukan bahwa jika nilai variabel laba sama dengan nol, maka nilai variabel return saham akan sebesar -0,020. Nilai koefisien regresi 
laba sebesar -0,003 menunjukan bahwa setiap peningkatan 1 persen EVA, akan menyebabkan penurunan return saham sebesar 0,003 persen.

Hasil regresi EVA pada return saham disajikan dalam Tabel 5 berikut.

Tabel 5.

Hasil Analisis Regresi Linear Sederhana EVA pada Return Saham

\begin{tabular}{|c|c|c|c|c|c|c|}
\hline & \multirow{2}{*}{ Model } & \multicolumn{2}{|c|}{$\begin{array}{l}\text { Unstandardized } \\
\text { Coefficients }\end{array}$} & \multirow{2}{*}{$\begin{array}{c}\text { Standardized } \\
\text { Coefficients } \\
\text { Beta }\end{array}$} & \multirow[t]{2}{*}{$\mathrm{T}$} & \multirow[t]{2}{*}{ Sig. } \\
\hline & & B & Std. Error & & & \\
\hline \multirow[b]{2}{*}{1} & (Constant) & -.028 & .018 & & -1.623 & .106 \\
\hline & $\begin{array}{l}\text { Economic Value } \\
\text { Added }\end{array}$ & 1.345 & .000 & .209 & 3.737 & .000 \\
\hline
\end{tabular}

Sumber: Data diolah, 2018

Nilai konstanta -0,028 menunjukan bahwa jika nilai variabel EVA sama dengan nol, maka nilai variabel return saham akan sebesar -0,028. Nilai koefisien regresi laba sebesar 1,345 menunjukan bahwa setiap peningkatan 1 persen laba, akan menyebabkan kenaikan return saham sebesar 1,345 persen.

Hasil regresi FVA pada return saham disajikan dalam Tabel 6 berikut.

Tabel 6.

Hasil Analisis Regresi Linear Sederhana EVA pada Return Saham

\begin{tabular}{|c|c|c|c|c|c|c|}
\hline & \multirow[t]{2}{*}{ Model } & \multicolumn{2}{|c|}{$\begin{array}{l}\text { Unstandardized } \\
\text { Coefficients }\end{array}$} & \multirow{2}{*}{$\begin{array}{c}\text { Standardized } \\
\text { Coefficients } \\
\text { Beta } \\
\end{array}$} & \multirow[t]{2}{*}{$\mathrm{t}$} & \multirow[t]{2}{*}{ Sig. } \\
\hline & & $\mathrm{B}$ & Std. Error & & & \\
\hline \multirow[b]{2}{*}{1} & (Constant) & -.029 & .018 & & -1.616 & .107 \\
\hline & $\begin{array}{l}\text { Economic Value } \\
\text { Added }\end{array}$ & 1.162 & .000 & .143 & 2.524 & .012 \\
\hline
\end{tabular}

Sumber: Data diolah, 2018

Nilai konstanta -0,029 menunjukan bahwa jika nilai variabel FVA sama dengan nol, maka nilai variabel return saham akan sebesar -0,029. Nilai koefisien regresi laba sebesar 1,162 menunjukan bahwa setiap peningkatan 1 persen laba, akan menyebabkan kenaikan return saham sebesar 1,162 persen. 
Dalam penelitian ini koefisien determinasi dilihat melalui nilai adjusted $R$ square. Adapun nilai dari adjusted $R$ square pada penelitian ini disajikan pada Tabel 5 berikut.

Tabel 7.

Hasil Koefisien Determinasi

\begin{tabular}{ccccc}
\hline & $\mathrm{R}$ & $R$ Square & Adjusted $R$ square & $\begin{array}{c}\text { Std. Error of the } \\
\text { Estimate }\end{array}$ \\
\hline Laba &, $085^{\mathrm{a}}$ &, 007 &, 004 &, 3090708 \\
EVA &, $209^{\mathrm{a}}$ &, 044 &, 041 &, 3033491 \\
FVA &, $143^{\mathrm{a}}$ &, 020 &, 017 &, 3070134 \\
\hline
\end{tabular}

Sumber: Data diolah, 2018

Berdasarkan hasil pengujian koefisien determinasi pada Tabel 5 dapat dijelaskan koefisien determinasi dari masing-masing variabel penelitian ini adalah nilai adjusted $R$ square variabel laba sebesar 0,04 dimana memiliki arti bahwa 0,4\% variasi perubahan return saham dapat dijelaskan oleh laba, sedangkan sisanya sebesar 99,6\% dipengaruhi oleh variabel lain di luar dari model regresi yang digunakan.

Nilai adjusted $R$ square variabel EVA sebesar 0,041 dimana memiliki arti bahwa $4,1 \%$ variasi perubahan return saham dapat dijelaskan oleh EVA, sedangkan sisanya sebesar $95.9 \%$ dipengaruhi oleh variabel lain di luar dari model regresi yang digunakan.

Nilai adjusted $R$ square variabel FVA sebesar 0,017 dimana memiliki arti bahwa $1,7 \%$ variasi perubahan return saham dapat dijelaskan oleh FVA, sedangkan sisanya sebesar 98,3\% dipengaruhi oleh variabel lain di luar dari model regresi yang digunakan.

Angka adjusted $R$ square digunakan untuk melihat dan membandingkan relative information content pada masing-masing variabel independen terhadap 
variabel dependen. Ketiga regresi yang dilakukan menghasilkan angka adjusted $R$ square dengan nilai rendah yang mengindikasikan bahwa return saham dapat dipengaruhi oleh berbagai informasi lain di luar informasi laba, EVA, maupun FVA. Zacharias dan Wirama (2015) menyatakan bahwa relevansi informasi dari laporan keuangan pada return saham dapat diukur menggunakan nilai adjusted $R$ square. Ketersediaan dan penggunaan informasi-informasi alternatif selain informasi dari laporan keuangan dalam penilaian perusahaan dapat menyebabkan penurunan relevansi nilai informasi akuntansi. Alternatif informasi lain dapat berasal dari informasi makro ekonomi secara global dan regional serta lingkungan bisnis.

Hipotesis pertama $\left(\mathrm{H}_{1}\right)$ yang dikemukakan dalam penelitian adalah economic value added lebih berpengaruh pada return saham dibandingkan dengan laba. Berdasarkan hasil uji koefisien determinasi, nilai adjusted $R$ square menunjukan hasil 0,041 pada EVA dan 0,004 pada laba, yang artinya economic value added memiliki relative information content lebih banyak dibandingkan dengan laba sehingga hipotesis diterima. Hal ini sesuai dengan pernyataan Stern Stewart selaku penemu metode EVA yang menyatakan bahwa pengukuran dengan EVA lebih baik dibandingkan dengan laba bersih, laba per saham, maupun pertumbuhan laba.

Sejalan dengan Shah (2015) dan Gupta (2016), yang melakukan analisis dengan menggunakan pendekatan konten informasi relatif dalam penelitiannya menyimpulkan bahwa EVA dapat menggambarkan nilai tambah saham dengan lebih baik dibandingkan dengan laba bersih. 
Hipotesis kedua $\left(\mathrm{H}_{2}\right)$ yang dikemukakan dalam penelitian adalah financial value added lebih berpengaruh pada return saham dibandingkan dengan laba. Berdasarkan hasil uji koefisien determinasi, nilai adjusted $R$ square menunjukan hasil 0,017 pada FVA dan 0,004 pada laba, yang artinya financial value added memiliki relative information content lebih banyak dibandingkan dengan laba sehingga hipotesis diterima.

Hipotesis pertama dan kedua menunjukkan hasil bahwa value added lebih berpengaruh terhadap return saham dibandingkan dengan laba. Proksi value added, yaitu EVA dan FVA memiliki konten informasi yang lebih relevan sehingga dapat menjelaskan variasi return saham secara lebih baik. Hal tersebut ditunjukkan oleh nilai adjusted $R$ square dari EVA dan FVA yang lebih besar dibandingkan dengan laba.

Pengukuran kinerja perusahaan dengan menggunakan laba merupakan hal yang sangat lazim dilakukan. Investor dapat melihat kinerja manajemen dalam menghasilkan keuntungan dari angka laba yang dihasilkan perusahaan. Meski demikian, dalam penelitian ini diperoleh hasil bahwa konten informasi relatif yang terkandung pada laba tidak lebih berpengaruh terhadap return saham jika dibandingan dengan informasi value added perusahaan. Kurmi dan Rakshit (2017) menyatakan bahwa pengukuran akuntansi tradisional seperti laba tidak dapat diandalkan karena tidak dapat mengukur perubahan nyata dalam nilai ekonomi. Perusahaan menciptakan nilai bagi pemegang saham ketika return pemegang saham melebihi return yang diperlukan untuk ekuitas dan liabilitas. Sehubungan dengan tujuan perusahaan bagi pemegang saham, kekayaan pemegang saham 
diukur dengan return yang diterima dari jumlah investasi. Pemegang saham mendapatkan return dalam dua bagian, yang pertama dalam bentuk dividen dan yang kedua dalam bentuk apresiasi modal tercermin dalam nilai pasar saham yang nilai pasarnya merupakan bagian yang dominan. Nilai pasar saham dipengaruhi oleh sejumlah faktor, salah satunya adalah harapan para pemegang saham terkait pengembalian investasi (Nagshbandi et al., 2016). Perusahaan diharapkan dapat menciptakan nilai bagi pemegang sahamnya, dan sudah seharusnya ada metode yang efektif untuk mengukur hal tersebut. Economic value added dan financial value added dapat menjadi alternatif pengukuran yang lebih baik untuk menggambarkan kinerja perusahaan dalam menciptakan nilai bagi pemegang sahamnya.

Hipotesis ketiga $\left(\mathrm{H}_{3}\right)$ yang dikemukakan dalam penelitian adalah financial value added lebih berpengaruh pada return saham dibandingkan dengan economic value added. Berdasarkan hasil uji koefisien determinasi, nilai adjusted $R$ square menunjukan hasil 0,017 pada FVA dan 0,041 pada EVA, yang artinya financial value added tidak memiliki relative information content lebih banyak dibandingkan dengan economic value added sehingga hipotesis ditolak.

Pengukuran kontribusi aset tetap dalam menghasilkan keuntungan bersih bagi perusahaan sebelumnya dinyatakan dapat mencocokkan hasil lebih baik pada net present value jika dibandingkan dengan perhitungan laba setelah dikurangi biaya modal. Pengukuran kontribusi aset tetap dapat menghasilkan harmonisasi hasil dengan NPV dalam ukuran tahunan. Pengukuran tersebut dapat menjadi alat 
kontrol yang baik, namun tidak dapat mengantisipasi fenomena bila perusahaan menjalankan investasi baru di tengah masa investasi yang diperhitungkan.

Implikasi teoretis hasil penelitian ini adalah diketahuinya perbandingan pengaruh laba, EVA, dan FVA pada return saham, dengan EVA sebagai variabel yang paling berpengaruh terhadap retun saham. Penelitian ini diharapkan akan memberikan kontribusi positif bagi semua pihak khususnya pihak akademisi, investor, dan perusahaan.

Penelitian ini memberikan implikasi bagi akademisi sebagai pengetahuan mengenai laba, value added, dan return saham. Bagi investor hasil penelitian ini dapat dijadikan sebagai bahan pertimbangan dalam mengambil keputusan investasi. Dalam menjalankan kegiatan opersional perusahaan, hasil penelitian ini juga diharapkan dapat membantu perusahaan dalam mempertimbangkan pengambilan keputusan keuangan perusahaan karena keputusan keuangan yang diambil akan memengaruhi preferensi investor terhadap prospek perusahaan di masa mendatang.

\section{SIMPULAN}

Economic value added lebih berpengaruh pada return saham dibandingkan dengan laba. Financial value added lebih berpengaruh pada return saham dibandingkan dengan laba. Financial value added tidak lebih berpengaruh pada return saham dibandingkan dengan economic value added.

Peneliti selanjutnya diharapkan menggunakan variabel serta proksi lain untuk menemukan variabel yang berasosiasi lebih baik dengan return saham. Para 
investor dan calon investor diharapkan mampu menerapkan berbagai metode pengukuran pada data keuangan yang dipublikasikan di Bursa Efek Indonesia agar dapat mengambil keputusan secara benar dalam berinvestasi di suatu perusahaan. Perusahaan dapat menerapkan value based measurement dalam pelaksanaan kegiatan operasi untuk menciptakan nilai tambah perusahaan.

\section{REFERENSI}

Awan, A. G., Siddique, K., \& Sarwar, G. (2014). The Effect Of Economic Value Added On Stock Return: Evidence From Selected Companies Of Karachi Stock Exchange. Research Journal of Finance and Accounting, 5(23), 140-152.

Baybordi, A., Barvari, F., Bahramihajiabad, T., \& Sheykhlou, M. (2015). Evaluating the Relationship between Economic Value-Added and Stock Return in Companies Listed at Tehran Stock Exchange. Management and Administrative $\quad$.., $\quad 3 \quad$ (2), $\quad 1307 \quad$ - 31311. http://www.absronline.org/journals/index.php/masr/article/view/414

Aprillianto, B., Wulandari, N., \& Kurrohman, T. (2014). Perilaku Investor Saham Individual Dalam Pengambilan Keputusan Investasi : Studi HermeneutikaKritis. E-Journal Ekonomi Bisnis Dan Akuntansi, 1-7.

Belkaoui, A. R. (2011). Teori Akuntansi. Jakarta: Salemba Empat.

Bhasin, M., Lal Bhasin, M., \& Bhasin, M. L. (2017). A Study of Economic Value Added Disclosures in the Annual Reports: Is EVA a Superior Measure of Corporate Performance? East Asian Journal of Business Economics, 5(1), 10-26. https://doi.org/10.20498/eajbe.2017.5.1.10

Brigham, E. F., \& Joel F, H. (2014). Dasar - dasar Manajemen Keuangan. Jakarta: Salemba Empat.

Christiani, I., \& Nugrahanti, Y. W. (2014). Pengaruh Kualitas Audit Terhadap Manajemen Laba. Jurnal Akuntansi Dan Keuangan, 16(1), 52-62. https://doi.org/10.9744/jak.16.1.52-62

Datu, C. V, \& Maredesa, D. (2017). Pengaruh Devidend Per Share Dan Earning Per Share Terhadap Harga Sahampada Perusahaan Go Public Di Bursa Efek Indonesia. Jurnal Riset Akuntansi Going Concern, 12(2), 1233-1242. 
Dorantes Dosamantes, C. A. (2013). The Relevance of Using Accounting Fundamentals in the Mexican Stock Market. Journal of Economics, Finance and Administrative Science. 18, 2-10. https://doi.org/10.1016/S2077-1886(13)70024-6

Firdausi, M. R., Rahadian, D., \& Dewi, A. S. (2017). Analisis Kinerja Keuangan dengan Menggunakan Metode Economic Value Added (EVA), Financial Value Added (FVA) dan Market Value Added (MVA) Studi Kasus pada Operator Telekomunikasi yang Terdaftar di BEI Periode 2008-2015. EProceedings of Management, 4(2), 1-10.

Ghozali, H. I. (2016). Aplikasi Analisis Multivariate dengan Program IBM SPSS 23 (Edisi Kedelapan). Semarang: Badan Penerbit Universitas Diponegoro.

Gupta, V. K., \& Sikarwar, E. (2016). Value creation of EVA and traditional accounting measures: Indian evidence. International Journal of Productivity and Performance Management. 65(4), hal.1-14. https://doi.org/10.1108/IJPPM-01-2014-0008

Hadi, N. (2013). Pasar Modal Acuan Teoritis dan Praktis Investasi di Instrumen Keuangan Pasar Modal. Yogyakarta: Graha Ilmu.

Hartono, J. (2015). Teori Portofolio dan Analisis Investasi. Yogyakarta: BPFE.

Hidajat, N. C. (2018). Pengaruh Return On Equity , Earnings Per Share , Economic Value Added, Dan Market Value Added Terhadap Return Saham Perusahaan Sektor Pertanian Yang Terdaftar Di Bursa Efek Indonesia Periode 2010-2016. Jurnal Ekonomi, XXIII(01), 62-75.

Hidayati, I. W. (2015). Analisis Economic Value Added ( Eva ) Dan Financial Value Added ( Fva ) Sebagai Salah Satu Alat Ukur Kinerja Keuangan Perusahaan ( Studi pada PT . Panca Mitra Multiperdana Periode 20102014 ). Jurnal Administrasi Bisnis, 25(2), 1-7.

Meckling, W. H., \& Jensen, M. C. (1976). Managerial behavior, agency costs and ownership structure. Journal of Financial Economics. 3(4), 305-360. https://doi.org/DOI: 10.1016/0304-405X(76)90026-X

Jianu, I., Jianu, I., Ileanu, B. V., Nedelcu, M. V., \& Herteliu, C. (2014). The value relevance of financial reporting in Romania. Economic Computation and Economic Cybernetics Studies and Research, 1-9. https://doi.org/10.2139/ssrn.3136611

Charles P. Jones. (2012). Investments Principles and Concepts (Twelfth). Wiley. 
Khan, U. A., Aleemi, A. R., \& Qureshi, M. A. (2016). Is Economic Value Added More Associated With Stock Price Than Accounting Earnings? Evidence From Pakistan. City University Research Journal, 6(2), 204-216. https://doi.org/10.1108/17439130610705526

Kurmi, M. K. (2017). Information Content Of EVA And Traditional Accounting Based Financial Performance Measures in Explaining Corporation' S Change Of Market Value. International Journal of Research in Finance and Marketing, 7(2), 1-14.

Naghshbandi, N., Chouhan, V., \& Jain, P. (2016). Value Based Measurement of Financial Performance. International Journal of Applied Research, 2(2), 365-369.

http://www.allresearchjournal.com/archives/2016/vol2issue2/PartF/2-225.pdf

Nakhaei, H., Hamid, N. I. N., Anuar, M. A., \& Nakhaei, K. (2016). Is refined economic value added more associated with stock return than accounting measures? The Malaysian evidence. Society and Economy in Central and Eastern Europe. 38(1), 69 - 85. https://doi.org/10.1556/204.2016.38.1.5

Nazemi, H. R., \& Abdoli, M. R. (2015). The Relationship of Stock Return with Earnings and Cash Flows before and after Financial Statement Restatements by the Companies Listed on the Tehran Stock Exchange. European Online Journal of Natural and Social Sciences 2015, 4(1), 7580 .

Pahlevi, R., Darminto, \& Handayani, S. R. (2013). Pengukuran Kinerja Keuangan Perusahaan Menggunakan Analis Rasio Keuangan dan Metode Economic Value Added (EVA). Journal of Chemical Information and Modeling. 2(1), 108 - 117. https://doi.org/10.1017/CBO9781107415324.004

Parwati, R. R. A. D., \& Sudiartha, G. M. (2016). Pengaruh Profitabilitas, Leverage, Likuiditas dan Penilaian Pasar Terhadap Return Saham Pada Perusahaan Manufaktur. Manajemen Unud. , 5(1), 385-413.

Putra, I. M. G., \& Dana, I. M. (2016). Pengaruh Profitabilitas, Leverage, Likuiditas dan Ukuran Perusahaan Terhadap Return Saham Perusahan Farmasi di BEI. E-Jurnal Akuntansi Universitas Udayana 9.2, 1-9.

Rodríguez Sandías, A., Fernandez Lopez, S., \& Otero González, L. (2002). Financial Value Added. SSRN. https://doi.org/10.2139/ssrn.296061

Rudianto. (2013). Akuntansi Manajemen. Jakarta: Erlangga.

Samadiyan, B., Pooryeganeh, N., Ebrahimi, H., \& Ghanbari, Y. (2013). Relative and Differential Information Content of Economic Value Added, Earnings, 
Operating Cash Flow and Stock Return. International Journal of Asian Social Science. 3(1), 29 - 37.

Sandhar, S. K., Verma, S., \& Nim, D. (2014). A Comparative Analysis Of Eva \& Mva Approach: With Special Reference To Automobile Industry. Journal of Commerce \& Accounting Research. 3, 40-46.

Sauro, M., \& Tafirei, M. (2016). EVA and Stock Returns: Are They Correlated. Financial Assets and Investing. 8(2), 34-51. https://doi.org/10.5817/FAI2016-2-3

Shah, R., Haldar, A., \& Nageswara Rao, S. V. D. (2016). Economic Value Added: Corporate Performance Measurement Tool. Corporate Board: Role, Duties and Composition. 11(1), $47 \quad-\quad 58$. https://doi.org/10.22495/cbv11i1art5

R, S. B., A, Z. Z., \& Azizah, D. F. (2014). Analisis Pengaruh Economic Value Added (EVA), Market Value Added (MVA), Dan Return On Investment (ROI), Terhadap Harga Saham (Studi Pada Perusahaan Property Dan Real Estate Yang Terdaftar Di Bursa Efek Indonesia Periode 2009-2012. Jurnal Administrasi Bisnis, 9(1), 1-9. administrasibisnis.studentjournal.ub.ac.id

Suandewi, I. G. A. A. S., \& Sudana, I. P. (2016). Rasio-Rasio Keuangan dan Return Saham. E-Jurnal Akuntansi. 16(1), 756-770.

Sugiyono. (2017). Metode Penelitian Kuantitatif, Kualitatif dan $R$ dan $D$. Banding: Alfabeta.

Tumbel, G. A., Tinangon, J., \& Walandow, S. K. (2017). Pengaruh Laba Akuntansi Dan Arus Kas Operasi Terhadap Return Saham Pada Perusahaan Manufaktur Sektor Industri Barang Konsumsi Yang Terdaftar Di Bursa Efek Indonesia. Emba. , 5(1), 173-183.

Utama, S. (2016). Aplikasi Analisis Kuantitatif. Denpasar: Fakultas Ekonomi Universitas Udayana.

Wang, J., Fu, G., \& Luo, C. (2013). Accounting information and stock price reaction of listed companies-empirical evidence from 60 listed companies in Shanghai Stock Exchange. Journal of Business \& Management. 2(3), $11-21$.

Wild, J. J., Subramanyam, K. R., \& Halsey, R. F. (2014). Analisis Laporan Keuangan (Edisi 10). Jakarta: Salemba Empat.

Yatmi, M. S. N., Astuti, D. S. P., \& Widarno, B. (2016). Pengaruh Laba Akuntansi dan Good Corporate Governance Terhadap Return Saham 
Perusahaan Peserta Corporate Governance Perception Index. Jurnal Akuntansi Dan Sistem Teknologi Informasi. 12(2), 193 - 199. https://doi.org/10.1007/3-540-45006-8_54

Yocelyn, A., \& Christiawan, Y. J. (2012). Analisis pengaruh perubahan arus kas dan laba akuntansi terhadap return saham pada perusahaan berkapitalisasi besar. Journal of Finance. 14(2), 81-90. https://doi.org/10.9744/jak.14.2.81-90

Yusbardini, Y. (2017). Economic Value Added vs Firm Performance. International Journal of Economic Perspectives, 11(1), 1683-1691.

Zacharias, J. A., \& Wirama, D. G. (2015). Kontribusi Nilai Buku dan Pendapatan dalam Menambah Relevansi Nilai Laba. E-Jurnal Ekonomi Dan Bisnis Universitas Udayana, 12, 1029-1060.

Zainal, R. (2013). Pengaruh Efektivitas Pengendalian Intern, asimetri informasi Dan kesesuaian kompensasi Terhadap Kecenderungan Kecurangan Akuntansi (Fraud). Universitas Negeri Padang. 1(3), 1-14. https://doi.org/10.1111/1467-8306.9302004 